\title{
ECONOMICS
}

\section{Measuring Governance: Why do errors matter?}

\author{
by
}

\section{Leandro M. Magnusson}

Business School

The University of Western Australia

and

\author{
Yashar Tarverdi \\ Bankwest Curtin Economics Centre \\ Curtin Business School \\ Curtin University
}




\title{
Measuring Governance: Why do errors matter?*
}

\author{
Leandro M. Magnusson ${ }^{\dagger 1}$ and Yashar Tarverdi $\ddagger 2$ \\ ${ }^{1}$ Department of Economics, The University of Western Australia \\ ${ }^{2}$ Bankwest Curtin Economics Centre, Curtin Business School, Curtin University
}

\begin{abstract}
The World Governance Indicators (WGI) are well-known proxies for institutions and widely used in many studies across different disciplines. Each of the six WGI are constructed by aggregating several baseline indicators using the Multiple Indicators Multiple Cause (MIMC) method. This method assumes that the errors associated to the baseline indicators are independent. Here, we extend the MIMC method by allowing cluster dependence among those errors. The differences between the original and re-estimates of the WGI are statistically significant. We compare the results of three highly cited papers to illustrate that the new indices can alter their conclusions.
\end{abstract}

Keywords: Governance Indicators, Measurement Error, MIMC, Institutions.

JEL Code: C43, C38, P16.

November 14, 2018

\footnotetext{
${ }^{*}$ We would like to thank participants of Australian PhD Conference in Economics and Business 2014, Australasian Development Economics Workshop 2015 \& 2018, BCEC Working Series Seminar, Prof. Alan Duncan, Prof. Ken Clements, Dr. Ratbek Dzhumashev and Dr. James Key. All errors belong to us.

${ }^{\dagger} \mathrm{M} 251,35$ Stirling Highway, The University of Western Australia, Crawley, WA 6009, Australia,phone: +61 (8) 6488-2924, fax: +61 (8) 6488-1016 leandro.magnusson@uwa.edu.au

${ }^{\ddagger}$ Building 408, Curtin University, Kent Street, Bentley, Perth, WA 6102 yashar.tarverdi@curtin.edu.au (corresponding author).
} 


\section{Introduction}

In the last two decades, research on the effect of institutions on economic development, in particular those covering governance and its aspects has flourished; see Boeninger (1991); Treisman (2000); Acemoglu et al. (2001); Acemoglu and Robinson (2000); Gupta and Abed (2002); Acemoglu et al. (2005). Governance, or institutions in general, is an unobservable variable. Therefore, one of the challenges in conducting empirical research is to obtain a measure that quantifies governance, even approximately. For that, Kaufmann et al. developed World Governance Indicators (WGI's), see Kaufmann et al. (1999, 2011).

The WGI, which are part of a long-standing research program of the World Bank consist of six aspects: (i) Control of Corruption (CC), (ii) Government Effectiveness (GE), Political Stability and Absence of Violence (PV), (iv) Regulatory Quality (RQ), (v) Rule of Law (RL), and (vi) Voice and Accountability (VA). For each aspect of WGI, countries' scores are reported and ranked accordingly. This has made the WGI popular across different disciplines, see JongSung and Khagram (2005), and Nunn (2008) from sociology; Tavits (2007) from political science; and Nunn (2007), Roodman (2007) and Acemoglu et al. (2014) from economics. The popularity and influence of WGI extend beyond the scholarly work: these indicators also serve as criteria for financial aid and debt forgiveness by the World Bank and developed countries, see Santiso et al. (2001); Grindle (2004); and Hout (2007).

Each aspect of WGI results from aggregating several indices. For example, 22 baseline indicators are combined for estimating the RL aspect, and 19 for computing the VA. The fundamental method behind this aggregation technique is the Multiple Indicators Multiple Cause (MIMC), pioneered by Goldberger (1972). The MIMC is extensively used in several strands of economics, psychology and sociology literature; see Bohrnstedt (1977); Siegel (1997); Paxton (1999); Maltritz et al. (2012); and Tekwe et al. (2014).

One underlying assumption for aggregating baseline indicators behind the WGI is that, conditional on the unobservable governance, the measurement error associated with each baseline indicator is independent from the others. This assumption is questionable when aggregating the baseline indicators, specially those which convey the same governance information. To clarify, consider the Rule of Law aspect: "Confidence in the police force" and "Confidence in judicial system" are two of its baseline indicators and both are provided by the Gallup World Poll. Expectedly, these indices are highly correlated, and are obtained from the same agency. 
Therefore, it is likely that their measurement errors are correlated as well. Yet, in construction of RL, the errors associated to those two baseline indicators are treated as independent from each other.

In this paper, we relax this independence assumption, proposing a method which allows a more flexible correlation structure among the baseline indicators. Our proposed extension of Goldberger]s MIMC nests the WGI's method.

We provide simulation evidence confirming that our method delivers better estimates of the latent variable than WGI's when the assumption of independence error terms is violated. We also reconstruct the WGI using our method, and graphically illustrate the differences between the original and proposed methods across countries. Moreover, we constructed an overall governance indicator based on our method.

We revisit the findings of Dollar and Kraay (2003), Acemoglu et al. (2014), and Winters and Martinez (2015) to show the empirical importance of our contribution. Having Rule of Law as a proxy for institutions, Dollar and Kraay (2003) argues the relative importance of institutions alongside of trade for economic growth. Using our modified Rule of Law, we show the statistically significant effect of institutions regardless of sample of countries and the regression method, which suggest the findings of Dollar and Kraay (2003) are robust against potential relationship between errors in measurement of institutions. For the second example, we obtain the same conclusion of Acemoglu et al. (2014); however, we find smaller magnitude of the effects of institution than those reported in the original paper. Such finding implies that the coefficients in Acemoglu et al. (2014) were overestimated because of the potential correlation of error terms in construction of institution variable. This is a significant result given that the main contribution of Acemoglu et al. (2014) is to correct the overestimated effects of human capital on economic growth found in the previous literature. In the third example, our results considerably differ from the ones originally reported in Winters and Martinez (2015), suggesting that governance is statistically insignificant for explaining the level and pattern of foreign aid and statistically significant coefficients in Winters and Martinez (2015) derived by the relationship between measurement error terms.

The outline of the paper is as follows: first we present our method, highlighting the differences to the original method by Kaufmann et al. (1999, 2011). In the next section we conduct simulation exercises to compare the performance of ours and Kaufmann et al.'s methodologies. Further comparison is conducted in Section 4, when we compare WGI with the ones computed 
using our method. A single governance indicator is presented in the following section. In Section 6 , we present the empirical applications illustrating the importance of our methods in applied work. Conclusion ends the paper.

\section{Estimating Governance Aspects}

The governance level of a country is inherently unobservable. Several indices, however, can reflect one aspect of the underlying governance level. For example, "Property Right" and "Law and Order" indices capture the "Rule of Law" aspect of governance, while "Corruption among government officials" and "Bribing and corruption exist in the economy" are related to "Control of Corruption" governance aspect 1 Thus, we assume that baseline indicators can be classified into $G$ groups, and each group corresponds, for example, to one governance aspect. When proposing the WGI, Kaufmann et al. (1999) assume six distinct governance aspects (i.e. six distinct groups), see further discussion in Kaufmann et al. (2011).

A typical group $g$ has $M$ baseline indicators in it, which are collected for $N$ countries. In Kaufmann et al. (1999, 2011), the relationship between the observed baseline indicator $m$ in group $g$ and the unobserved governance for a country $n$ is represented as

$$
y_{n, g, m}=\alpha_{g, m}+\beta_{g, m}\left(y_{n, g}^{*}+\epsilon_{n, g, m}\right)
$$

where $y_{n, g}^{*}$ is the unobserved governance aspect $g$ in country $n, n=1, . ., N$, which follows a standard normal distribution, $y_{n, g}^{*} \sim N(0,1)$. The parameters $\alpha_{g, m}$ and $\beta_{g, m}$ are scalars, with $\alpha_{g, m}$ capturing differences in the scale across indicators. The error term $\epsilon_{n, g, m}$ is assumed to be independently, normally distributed, $\epsilon_{n, g, m} \sim N\left(0, \sigma_{\epsilon, g, m}^{2}\right)$.

One can demonstrate that the (conditional) expectation and variance of a governance aspect $g$ in country $n$ are, respectively,

$$
\mathrm{E}\left[y_{n, g}^{*} \mid \mathbf{y}_{n, g}\right]=\sum_{m=1}^{M} w_{g, m}\left(\frac{y_{n, g, m}-\alpha_{g, m}}{\beta_{g, m}}\right)
$$

\footnotetext{
1"Property Rights" and "Law and Order" are obtained from the Heritage Foundation Index of Economic Freedom and the Political Risk Services International Country Risk Guide, respectively. "Public Trust in Politicians" and "Bribing and corruption exist in the economy" are indices of Institute for Management and Development World Competitiveness Yearbook and "World Economic Forum Global Competitiveness Report", respectively.
} 
and

$$
\operatorname{var}\left[y_{n, g}^{*} \mid \mathbf{y}_{n, g}\right]=\left[1+\sum_{m=1}^{M}\left(\sigma_{\epsilon, g, m}^{2}\right)^{-1}\right]^{-1},
$$

where $w_{g, m}=\left(\frac{\operatorname{var}\left[y_{n, g}^{*} \mid \mathbf{y}_{n, g}\right]}{\sigma_{\epsilon, g, m}^{2}}\right)$ is the weight that depends on the conditional variance, and $\mathbf{y}_{n, g}=$ $\left(y_{n, g, 1}, y_{n, g, 2}, \ldots, y_{n, g, M}\right)^{\prime}$ is the collection of all subindices in group $g$ for country $n$. One could obtain estimates of $\mathrm{E}\left[y_{n, g}^{*} \mid \mathbf{y}_{n, g}\right]$ and $\operatorname{var}\left[y_{n, g}^{*} \mid \mathbf{y}_{n, g}\right]$ by replacing $\left\{\alpha_{g, m}, \beta_{g, m}, \sigma_{\epsilon, g, m}^{2}\right\}_{m=1}^{M}$ with their respective maximum likelihood estimates.

The MIMC method used by Kaufmann et al. (1999, 2011) assumes that the error terms in equation (1) are independent. To put this assumption in perspective we can take the Rule of Law (RL) as an example; RL is constructed using 21 baselines measures such as Private Property Protection (from the Economist Intelligence Unit), Personal and Private Property Security (from the Institute for Management Development World Competitiveness Yearbook) and Property Rights (from the Heritage Foundation Index of Economic Freedom). Those indices are highly correlated, and, potentially, their associated measurement errors are as well. The main focus of this work is to relax this assumption.

\section{The New Governance Indicators}

With a slight re-parametrization it is possible to represent equation (1) as

$$
y_{n, g, m}=\alpha_{g, m}+\beta_{g, m} y_{n, g}^{*}+u_{n, g, m}
$$

We also assume that $y_{n, g}^{*} \sim N(0,1)$, and the error term $u_{n, g, m}$ can be decomposed as

$$
u_{n, g, m}=v_{g}+\varepsilon_{n, g, m}
$$

where $v_{g}$ is a (random) group effect, and $\varepsilon_{n, g, m}$ is an idiosyncratic error. We further assume that, conditional on the unobserved governance, $v_{g}$ and $\varepsilon_{n, g, m}$ follow independent normal distributions, with mean 0 and variances $\sigma_{v_{g}}^{2}$ and $\sigma_{\varepsilon, g, m}^{2}$, respectively. Therefore, errors associated to baseline indices are correlated among themselves. By stacking the baseline indices in group $g$ we rewrite equation (3) as

$$
\mathbf{y}_{n, g}=\mathbf{a}_{g}+\mathbf{b}_{g} y_{n, g}^{*}+\iota_{g} v_{g}+\varepsilon_{n, g}
$$


where $\mathbf{a}_{g}=\left(\alpha_{g, 1}, \ldots, \alpha_{g, M}\right)^{\prime}, \mathbf{b}_{g}=\left(\beta_{g, 1}, \ldots, \beta_{g, M}\right)^{\prime}$, and $\iota_{g}$ is a vector of ones with dimension $M \times 1$. From equation (5) we find that the (conditional) variance of $\mathbf{y}_{n, g}$ is

$$
\operatorname{var}\left(\mathbf{y}_{n, g} \mid y_{n, g}^{*}\right)=\Sigma_{v_{g}}+\Sigma_{\varepsilon_{g}}
$$

where $\Sigma_{v_{g}}=\sigma_{v_{g}}^{2} \iota_{g} \boldsymbol{\iota}_{g}^{\prime}$ and $\Sigma_{\varepsilon, g}=\operatorname{diag}\left\{\sigma_{\varepsilon, g, m}^{2}\right\}_{m=1}^{M}$ are $M \times M$ square matrices. Following the properties of multivariate normal distribution, we obtain the (conditional) expectation and variance of $g^{\text {th }}$ governance aspect in country $n$

$$
\mathrm{E}\left(y_{n, g}^{*} \mid \mathbf{y}_{n, g}\right)=\operatorname{var}\left(y_{n, g}^{*} \mid \mathbf{y}_{n, g}\right) \mathbf{b}_{g}^{\prime}\left(\Sigma_{v_{g}}+\Sigma_{\varepsilon_{g}}\right)^{-1}\left(\mathbf{y}_{n, g}-\mathbf{a}_{g}\right)
$$

and

$$
\operatorname{var}\left(y_{n, g}^{*} \mid \mathbf{y}_{n, g}\right)=\left[1+\mathbf{b}_{g}^{\prime}\left(\Sigma_{v_{g}}+\Sigma_{\varepsilon_{g}}\right)^{-1} \mathbf{b}_{g}\right]^{-1}
$$

We can estimate $\mathrm{E}\left(y_{n, g}^{*} \mid \mathbf{y}_{n, g}\right)$ and $\operatorname{var}\left(y_{n, g}^{*} \mid \mathbf{y}_{n, g}\right)$ by maximum likelihood. The contribution of each country $n$ to the log-likelihood function is

$$
\ell_{n}\left(\left\{\mathbf{a}_{g}, \mathbf{b}_{g}, \Sigma_{v_{g}}, \Sigma_{\varepsilon_{g}}\right\}\right) \propto \ln \left|\Omega_{g}\right|+\left(\mathbf{y}_{n, g}-\mathbf{a}_{g}\right)^{\prime} \Omega_{g}^{-1}\left(\mathbf{y}_{n, g}-\mathbf{a}_{g}\right)
$$

where $\Omega_{g}=\mathbf{b}_{g} \mathbf{b}_{g}^{\prime}+\Sigma_{v_{g}}+\Sigma_{\varepsilon_{g}}$.

If we ignore the cluster dependence, i.e. $\Sigma_{v}=0$, then the method becomes similar to that of Kaufmann et al. (1999). Therefore, our method encompasses the WGI's and our proposed extension is a testable hypothesis.

Although we also only consider one group effect in the error term, the method can allow for several groups effect. For example, assuming that we have two independent clusters of baseline indicators, we can redefine the error term as

$$
u_{n, g, m}=v_{g} D_{g}+\eta_{g}\left(1-D_{g}\right)+\varepsilon_{n, g, m}
$$

where $D_{g}$ is a dummy variable for the subgroup of baseline indicators associated to the $v_{g}$ effect, while the remaining baseline indicators are associated to the $\eta_{g}$. However, care is needed when adding extra group effects, because this addition cannot violate the order condition for estimating the parameters in the likelihood.

In the previous exposition, we implicitly assume that the number of baseline indicators for a 
certain governance aspect is equal across countries. In practice, however, this number can vary across countries. Our proposed method can accommodate unbalanced cases as well, similar to the method used in Kaufmann et al. (2011).

\section{Simulation Study}

We compared the properties of the original method and the proposed method for estimating the governance indicator via running two simulation exercises. The first exercise shows the better performance of our proposed method when there is a dependency between error terms, while in the second exercise, we illustrate the magnitude of the bias of the estimated governance when the level of dependency varies.

\section{First Simulation Exercise}

In our simulations we assume that there are 15 baseline indicators $(M=15)$ that cover 200 countries $(N=200)$. Omitting the subscript $g$ for clarity, for each simulation we generated a normally distributed random variables, $y_{n}^{*}$, and $\varepsilon_{n}$. We consider two group effects $v_{1}$ and $v_{2}$ which are independent and normally distributed as well with variances $\sigma_{v_{1}}^{2}$ and $\sigma_{v_{2}}^{2}$, respectively. Group 1 is formed by the baseline indicators 1 to 10, while group 2 contains the remaining baseline indicators. The parameters of $\mathbf{a}, \mathbf{b}, \sigma_{v_{1}}^{2}, \sigma_{v_{2}}^{2}$ and $\sigma_{\varepsilon}^{2}$ are randomly generated, but kept fixed in all simulations, see equation (5) and the paragraph below it. The number of simulation experiments are 1,000 .

For each simulation, we compute the mean squared error (MSE) which is given by

$$
M S E_{s}=\frac{\sum_{i=1}^{N}\left(\hat{y}_{i, s}^{*}-y_{i}^{*}\right)^{2}}{N}
$$

where $\hat{y}_{i, s}^{*}$ is the estimated value of governance in country $i$ at simulation $s$.

By ordering $y_{i}^{*}$ and $\hat{y}_{i, s}^{*}$ we obtain the rank and its estimate for each country, which we define as $r_{i}$ and $\hat{r}_{i, s}$, respectively. We also compute the probability of success which is the average difference between the estimated and true ranks, defined as

$$
\operatorname{Prob}(h)_{s}=\frac{\sum_{i=1}^{N} I\left(\left|\hat{r}_{i, s}^{*}-r_{i}^{*}\right| \leq h\right)}{N}
$$

where $I(\cdot)$ is an indicator function, and $h$ is a natural number indicating the highest acceptable 
difference between the estimated and true ranks.

We investigate two cases. The first one is when the countries have all baseline indicators, this is a balanced data scenario. The second case, with unbalanced data, countries have a different number of baseline indicators. In the unbalanced case, we partition countries into two groups: the ones which have all indicators, for example, countries 1 to $N_{1}$, and countries with some but not all indicators available, countries $N_{1}+1$ to $N$. Using $\left\{\mathbf{y}_{n}\right\}_{n=1}^{N_{1}}$, we estimate $\mathbf{a}, \mathbf{b}, \Sigma_{v}$, and $\Sigma_{\varepsilon}$. Then we obtain $\left\{\hat{y}_{i}^{*}\right\}_{n=N_{1}+1}^{N}$ using $\hat{\mathbf{a}}, \hat{\mathbf{b}}, \hat{\Sigma}_{v}$, and $\hat{\Sigma}_{\varepsilon}$, the estimates of $\mathbf{a}, \mathbf{b}, \Sigma_{v}$, and $\Sigma_{\varepsilon}$, respectively, together with the available indicators for countries with unbalanced data. The next step is to estimate the missing indicators for the latter countries using the estimated parameters and $\left\{\hat{y}_{i}^{*}\right\}_{n=N_{1}+1}^{N}$. Finally, combining observable and estimated indicators for countries with unbalanced data, governance is re-estimated using all countries.

The results of the average MSE and probability of "success" are in Table 1

\section{[Table 1 about here.]}

Table 1 confirms that if the initial assumption of independent error terms is relaxed, our method has lower MSE and higher precision in ranking countries in comparison with the WGI method 2

\section{Second Simulation Exercise}

In the second simulation exercise, we investigate how the changes in the group effect impacts the governance estimation according to the WGI and the proposed methods. We kept the same simulation design, similar to the previous exercise with balanced data, but we fixed $\sigma_{v_{2}}^{2}$ as

$$
\sigma_{v_{2}}^{2}=\sigma_{v_{1}}^{2}+c
$$

where $\mathrm{c}$ is a constant.

Next, we compute the average MSE of the original WGI and the proposed methods for increasing values of $\sigma_{v_{1}}^{2}$. In this simulation exercise we set $c=0.75$, but the results remain the same for different values of $c$. Figure 1 reports the variation MSE values according to $\sigma_{v_{1}}^{2}$. We also include bands indicating the minimum and maximum values of the MSE.

\footnotetext{
${ }^{2}$ In this particular exercise, the better estimates in the unbalanced case are due to the re-estimation process. We observe that the re-estimation process reduces the bias significantly. This result, however, cannot be generalized.
} 
[Figure 1 about here.]

The WGI and the proposed methods similarly perform with lower values of $\sigma_{v_{1}}^{2}$. As $\sigma_{v_{1}}^{2}$ increases, our method outperforms the original WGI method in terms of MSE.

\section{Comparing Original and Re-estimated WGI}

In this section, we employ our method to re-estimate the six governance aspects covered by the WGI. We use the same 101 baseline indicators as WGI for the 2012-13 period, which cover 179 countries. The number of baseline indicators for each governance aspect are in Table 2, In re-estimating the governance aspects, we consider a single group effect as illustrated by equation (4).

[Table 2 about here.]

Figures 2 and 3 contain the new and original estimates of governance aspects. In the horizontal axis, we rank the countries according to the new estimates. The green line represents the re-estimated aspects while the red line is the original WGI. In the same figures, we add the bands representing the $95 \%$ confidence interval of WGI aspects. Both the WGI indices and their respective confidence bands were retrieved from the World Bank webpage http://info. worldbank.org/governance/wgi/\#home. We also include horizontal dashed lines marking the $25^{t h}, 50^{\text {th }}$ and $75^{\text {th }}$ percentiles of the countries ranked according to the re-estimated aspects.

[Figure 2 about here.]

[Figure 3 about here.]

Figures 2 and 3 highlights the differences among the original and re-estimated governance aspects vividly. Such differences can be important when using the WGI in empirical research, a point further explored on the following section.

There are cases in which the ranks of countries obtained by the re-estimated and original WGI aspects are quite distinct from each other, as in the Control of Corruption and Rule of Law, see Figures $3 \mathrm{a}$ and $3 \mathrm{~b}$. For example, while Nicaragua is ranked at the $50^{\text {th }}$ percentile for the re-estimated Rule of Law aspect, it scores, at around $20^{\text {th }}$ under the original WGI, representing a 30 rank drop. Another example is Ghana, which is ranked at the $80^{\text {th }}$ percentile for Control and Corruption using the re-estimated indicator, and only at $55^{\text {th }}$ percentile using the original WGI. 
In both examples, the differences between the original and estimated indicators are statistically significant.

There are, however, governance aspects in which the original and new estimates rank countries similarly, as with the Political Stability \& Absence of Violence index and the Voice \& Accountability index, see Figures 2b and 2c In the case of the Political Stability \& Absence of Violence index, the countries located at the first to the ninth deciles are basically the same, and the differences among the re-estimated and original values are not statistically significant.

These results suggest that there are governance aspects in which the underlying cluster effect among baseline indicators are more prominent, as in the Rule of Law, and others in which the effect can be ignored, as in the Political Stability \& Absence of Violence. Since the proposed method encompasses the original one, the insignificance of the cluster effect is a testable hypothesis which can be conduct by applying a simple likelihood ratio test for testing the null assumption $\mathcal{H}_{o}: \sigma_{v_{g}}^{2}=0$ against the alternative $\mathcal{H}_{o}: \sigma_{v_{g}}^{2}>0$. The results are reported in Table 3 ,

[Table 3 about here.]

Table 3 shows that the $\mathcal{H}_{o}$ is statistically rejected in almost all cases, illustrating that the new model specification which accounts for cluster effects is statistically preferred over the one that ignores its presence. The only exception is the PV aspect where the $\mathcal{H}_{o}$ is not rejected at $5 \%$ significance level, suggesting that PV is less likely to suffer from cluster effects among the baseline indicators, see also Figure 2b.

Overall findings from Table 3 corroborate with some of Langbein and Knack (2010)'s criticisms on WGI. For instance, Langbein and Knack (2010) assert that baseline indicators for each aspect of WGI should be treated independently, as the relationship between the baseline indicator could be something of aspect specific.

\section{A Single Governance Index}

In many empirical works as well as policy debates, one single index of governance is preferable. To overcome the multi-dimensionality of the WGI, researchers use different methods to aggregate the six measures into one, as the principal component analysis in Tarverdi and Rammohan (2017) or the sample average across the WGI's in Winters and Martinez (2015). In this section, we extend our proposed method to estimate a unique governance index. 
The proposed method can accommodate different ways of clustering the errors; however, for obtaining the single governance indicator, we cluster the errors based on the six WGI groups. For example, the Freedom House Democracy Index (FRH) and the Reporters without Borders Press Freedom Index (RSF), which provide information on democratic aspects of governance, are in the Voice and Accountability aspect; therefore, we include them in the same cluster. We assume that the error terms associated with the conceptually close indicators would be correlated, but be independent of the error terms in other clusters.

The comparison between the average of WGI's and the new single governance indicator (New-GI) is in Figure 4. The percentile rank of countries is at the horizontal axis, with the values of the indices on vertical axis. The smooth line represents the New-GI, while the ragged red line represents the mean of the WGI. The grey shade area represents the range between maximums and minimums of the six WGI for each country. Horizontal dashed lines marking the $25^{\text {th }}, 50^{\text {th }}$ and $75^{\text {th }}$ percentiles of the New-GI are also included.

[Figure 4 about here.]

The New-GI indicator stays within the range of the minimum and maximum values of the WGI for most of the countries; however, it is clear that the New-GI differs from the average of WGI.

In Figure 5, the New-GI is depicted against the WGI for six countries: Denmark (2.01) and Somalia (-2.29) as top and bottom countries respectively according to the New-GI, with Bolivia (-0.17), Kuwait (0.16), Turkey (0.10) and Peru (0.29) representing the middle-ranked countries. In all of the charts, the leftmost bar represents the new single governance index, while the remaining bars are the six WGI with the arrows representing the $95 \%$ confidence intervals.

[Figure 5 about here.]

For Denmark, depicted in Figure 5a, the New-GI and WGI's are on the same direction and positive but in Somalia's case the indexes are negative, see Figure $5 \mathrm{~b}$. More interesting are the indicators for the mid-level countries, which present substantial variation across different aspects of governance. For example, Figure $5 \mathrm{c}$ shows that Kuwait has a relatively good level of RL, but significantly lacks in VA. Despite of these variations, the New-GI appears to be successful in summarising the differences across aspects. For Bolivia and Peru, see Figures $5 \mathrm{~d}$ and $5 f$ the New-GI is well above the average WGI and this difference is statistically significant. 
Such differences can be important when conducting applied work, which we illustrate in the following section.

\section{Empirical Examples}

In this section, we explore how relaxing the initial assumption of WGI's method can affect empirical research. We focus on three manuscripts: Dollar and Kraay (2003), Acemoglu et al. (2014), and Winters and Martinez (2015).

Dollar and Kraay explore the impact of institutions and trade on economic growth. The authors find a positive effect of institutions on economic growth while the effect of trade seems not to be statistically significant, at least not in the short run. However, the long run specification shows trade to have a more significant role on economic growth than institutions. Dollar and Kraay used the WGI only in their short run models, therefore our focus will be just on them.

In the second manuscript, Acemoglu et al. (2014) study the effects of institutions and human capital on economic development. Most studies in this research area report that the role of human capital is more important than institutions in explaining economic growth. Acemoglu et al. (2014), on the contrary, argue that it is the institutions, measured by Rule of Law, which have the higher effect on economic growth.

The third manuscript is Winters and Martinez (2015)'s research about the role of governance on international aid. The authors assert that donors are selective in favor of countries with better governance and they are so by selecting desired combinations of projects and sectors for aid donations.

The first two papers are cross sectional studies with the Rule of Law as the proxy for institutions. The third paper uses panel data and has the average of the six WGI as the measure of governance.

\subsection{Institutions, Trade and Growth}

Dollar and Kraay (2003) explores the importance of institutions and trade on economic growth. Running a series of regressions in a cross-section of countries, the authors document that, in short run, the statistical significance of Rule of Law (i.e. institutions) on economic growth is highly dependent on the choice of instrumental variables and country sample. They do not find evidence of trade in the economic growth in the short run. 
Table 4 presents the original results of Dollar and Kraay (2003) together with those obtained by using the re-constructed Rule of Law.

\section{[Table 4 about here.]}

Different from the original ones, the results based on the re-constructed RL show statistically significant effect of institutions on economic growth in most of the specifications; however, they yield smaller coefficients. We also find that the trade effect on economic growth in the short run is relevant in two of the five specifications.

\subsection{Institutions, Human Capital and Development}

Acemoglu et al. (2014) investigate the joint effect of institutions and human capital on economic development. As a major contribution to the research in this area, the authors find that the effect of human capital is considerably lower than previously documented. Moreover, they find that the role of institutions on economic growth is more important than human capital. Acemoglu et al. argue that the existing research is misleading because it ignores the presence of the omitted variable bias and measurement error in both human capital and institutions. They apply instrumental variables (IV) estimation to circumvent the endogeneity of the main explanatory variables.

In (Acemoglu et al., 2014), human capital is measured by total years of schooling, while the 2005's Rule of Law serves as proxy for institutions. In Figure 6, the re-constructed and original RL indicators are plotted against the percentile rank of the countries. The description of the graph is the same as those in Figures 2 and 3.

[Figure 6 about here.]

Table 5 presents the results based on the original and re-estimated 2005's RL. 3

[Table 5 about here.]

The results using the re-estimated 2005 RL confirm Acemoglu et al.'s findings. After controlling for endogeneity, the effect of RL is statistically significant but the same is not true for the total years of schooling; however, the effect of RL is smaller than those reported in the original paper. The re-estimated RL also shows higher identification power of the instruments (lower p-value of Kleibergen and Paap (2006) rank test), and better regression fit as measured by the $R^{2}$ s.

\footnotetext{
${ }^{3}$ We replicate original estimates using the Acemoglu et al. (2014) online code and data. The results slightly differ from the published ones as acknowledged by the authors.
} 


\subsection{Governance and International Aid}

Winters and Martinez (2015) explore the effect of governance on level and pattern of aid allocation across different sectors. Acknowledging that governance is positively linked to more financial aid, the authors show that, when faced with poorly governed countries, donors are selective and are in favor of the projects in which they have more control. They use a panel data sample covering 41 donors in the period 2004 to 2010, and average all six WGI to obtain a single governance index for each country. In reproducing the results, we, instead, use an overall governance index as explained in Section 5

Table 6 presents the original results together with the ones obtained using the new overall governance indicator (New-GI). Incorporating the new indicator changes the sample size slightly, that is because the original paper averaged the six existing WGI, whereas we considered all the baseline indicators and aggregated them into one. To ensure that the changes in the sample size does not affect any of the final conclusions and observed differences, in Table 6, we also report the results based on our sample but using the original measure. We show that regardless of the sample size, using the original measure yields the same conclusion.

\section{[Table 6 about here.]}

However, different from the results reported in Winters and Martinez (2015), we find that the effect of governance is insignificant at $5 \%$ significance, when using the new indicator.

To further investigate the differences in the estimation results, we plot the two measures of governance in Figure 7. In this figure, the dots represent countries with corresponding values from New-GI on the horizontal axis, and the average of the WGI on the vertical axis. The relationship between the two governance measures is strongly positive, as expected. The observed heterogeneity, however, makes the results using the average WGI and the New-GI differ.

[Figure 7 about here.]

The findings using the New-GI are aligned with those reported in Santiso et al. (2001); Neumayer (2002, 2005); Thiele et al. (2007); Epstein and Gang (2009), and Tarverdi and Rammohan (2017). That is, the exact pattern of aid allocation is not related to improvements in governance or the actual need of recipient country and it is potentially related to other factors such as shared heritage or bilateral trade. 


\section{Conclusion}

This study builds on the methodology used by Kaufmann et al. (1999, 2011), to propose a novel method that is also a methodological contribution to Goldberger (1972)'s MIMC method. Our method allows for a more flexible framework to be used in the aggregation of some baseline indicators, while accounting for the relationship between the relevant error terms. The potential dependency of error terms was ignored in Goldberger (1972) and Kaufmann et al. (1999, 2011).

Our method accounts for dependency of error terms by the introduction of a group effect. Through a few simulation studies, we show that even with small correlation among the error terms, our method performs much better in retrieving the simulated latent variable (i.e. governance) than those methods proposed in Kaufmann et al. (1999, 2011) and Goldberger (1972). We apply our method to the same data and re-estimate the original WGI and consequently revisited three significant empirical works: Dollar and Kraay (2003), Acemoglu et al. (2014), and Winters and Martinez (2015). We illustrate that some of the initial assumption made in construction of WGI, or in original MIMC, have very substantial impact on conclusion and findings of some of the highly cited works. 


\section{Bibliography}

Acemoglu, D., F. A. Gallego, and J. A. Robinson (2014). Institutions, human capital, and development. Annual Review of Economics 6(1), 875-912.

Acemoglu, D., S. Johnson, and J. A. Robinson (2001, December). The Colonial Origins of Comparative Development: An Empirical Investigation. American Economic Review 91(5), 1369-1401.

Acemoglu, D., S. Johnson, and J. A. Robinson (2005). Chapter 6 institutions as a fundamental cause of long-run growth. Volume 1, Part A of Handbook of Economic Growth, pp. $385-472$. Elsevier.

Acemoglu, D. and J. A. Robinson (2000). Political losers as a barrier to economic development. The American Economic Review 90(2), 126-130.

Boeninger, E. (1991). Governance and development: Issues and constraints. The World Bank Economic Review 5(1), 267-287.

Bohrnstedt, G. W. (1977). Use of the Multiple Indicators-Multiple Causes (MIMC) model. American Sociological Review 42(4), 656-663.

Dollar, D. and A. Kraay (2003). Institutions, trade, and growth. Journal of Monetary Economics 50(1), 133 - 162.

Epstein, G. S. and I. N. Gang (2009). Good governance and good aid allocation. Journal of Development Economics 89(1), 12-18.

Goldberger, A. S. (1972). Maximum-likelihood estimation of regressions containing unobservable independent variables. International Economic Review 13(1), 1-15.

Grindle, M. S. (2004). Good enough governance: Poverty reduction and reform in developing countries. Governance $17(4), 525-548$.

Gupta, S. and G. Abed (2002). Governance, Corruption, and Economic Performance. International Monetary Fund (IMF).

Hout, W. (2007). The Politics of Aid Selectivity: Good Governance Criteria in World Bank, U.S. and Dutch Development Assistance. Routledge Studies in Development Economics. Taylor \& Francis. 
Jong-Sung, Y. and S. Khagram (2005). A comparative study of inequality and corruption. American Sociological Review 70(1), 136-157.

Kaufmann, D., A. Kraay, and M. Mastruzzi (2011). The worldwide governance indicators: Methodology and analytical issues. Hague Journal on the Rule of Law 3(2), 220-246.

Kaufmann, D., A. Kraay, and P. Zoido-Lobatón (1999). Aggregating governance indicators, Volume 2195. World Bank Publications.

Kleibergen, F. and R. Paap (2006). Generalized reduced rank tests using the singular value decomposition. Journal of Econometrics 133(1), 97 - 126.

Langbein, L. and S. Knack (2010). The worldwide governance indicators: six, one, or none? The Journal of Development Studies 46(2), 350-370.

Maltritz, D., A. Bühn, and S. Eichler (2012). Modelling country default risk as a latent variable: a multiple indicators multiple causes approach. Applied Economics 44(36), 4679-4688.

Neumayer, E. (2002). Is good governance rewarded? a cross-national analysis of debt forgiveness. World Development 30(6), 913-930.

Neumayer, E. (2005). The Pattern of Aid Giving: The Impact of Good Governance on Development Assistance. Routledge Studies in Development Economics. Taylor \& Francis.

Nunn, N. (2007). Relationship-specificity, incomplete contracts, and the pattern of trade*. The Quarterly Journal of Economics 122(2), 569.

Nunn, N. (2008). The long-term effects of Africa's slave trades*. The Quarterly Journal of Economics 123(1), 139.

Paxton, P. (1999). Is social capital declining in the United States? a multiple indicator assessment. American Journal of Sociology 105(1), 88-127.

Roodman, D. (2007). The anarchy of numbers: Aid, development, and cross-country empirics. The World Bank Economic Review 21(2), 255.

Santiso, C. et al. (2001). World bank and good governance: good governance and aid effectiveness: the world bank and conditionality. Geo. Public Pol'y Rev. 7, 1-137. 
Siegel, D. (1997). The impact of computers on manufacturing productivity growth: A multipleindicators, multiple-causes approach. The Review of Economics and Statistics 79(1), 68-78.

Tarverdi, Y. and A. Rammohan (2017). On the role of governance and health aid on child mortality: a cross-country analysis. Applied Economics 49(9), 845-859.

Tavits, M. (2007). Clarity of responsibility and corruption. American journal of political science 51(1), 218-229.

Tekwe, C. D., R. L. Carter, H. M. Cullings, and R. J. Carroll (2014). Multiple indicators, multiple causes measurement error models. Statistics in Medicine 33(25), 4469-4481.

Thiele, R., P. Nunnenkamp, and A. Dreher (2007). Do donors target aid in line with the Millennium Development Goals? a sector perspective of aid allocation. Review of World Economics 143(4), 596-630.

Treisman, D. (2000). The causes of corruption: a cross-national study. Journal of Public Economics 76(3), $399-457$.

Winters, M. S. and G. Martinez (2015). The role of governance in determining foreign aid flow composition. World Development 66, $516-531$. 


\section{List of Figures}

$1 \quad$ Group effect and changes in mean squared errors . . . . . . . . . . . . . . . . . 19

$2 \quad$ Reproduction of WGI $\ldots \ldots \ldots \ldots \ldots \ldots \ldots \ldots$

$3 \quad$ Reproduction of WGIII $\ldots \ldots \ldots \ldots \ldots \ldots \ldots \ldots \ldots$

4 The New GI against the maximum and minimums of the WGI . . . . . . . . 22

$5 \quad$ The WGI and the New Governance Index . . . . . . . . . . . . . . . . . 23

$6 \quad$ The original and re-estimated 2005 Rule of Law index . . . . . . . . . . . . . . . 24

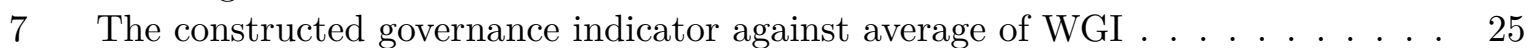


Variation in $\sigma_{v_{1}}^{2}$ and changes in Mean Squared Error



Figure 1: Group effect and changes in mean squared errors 


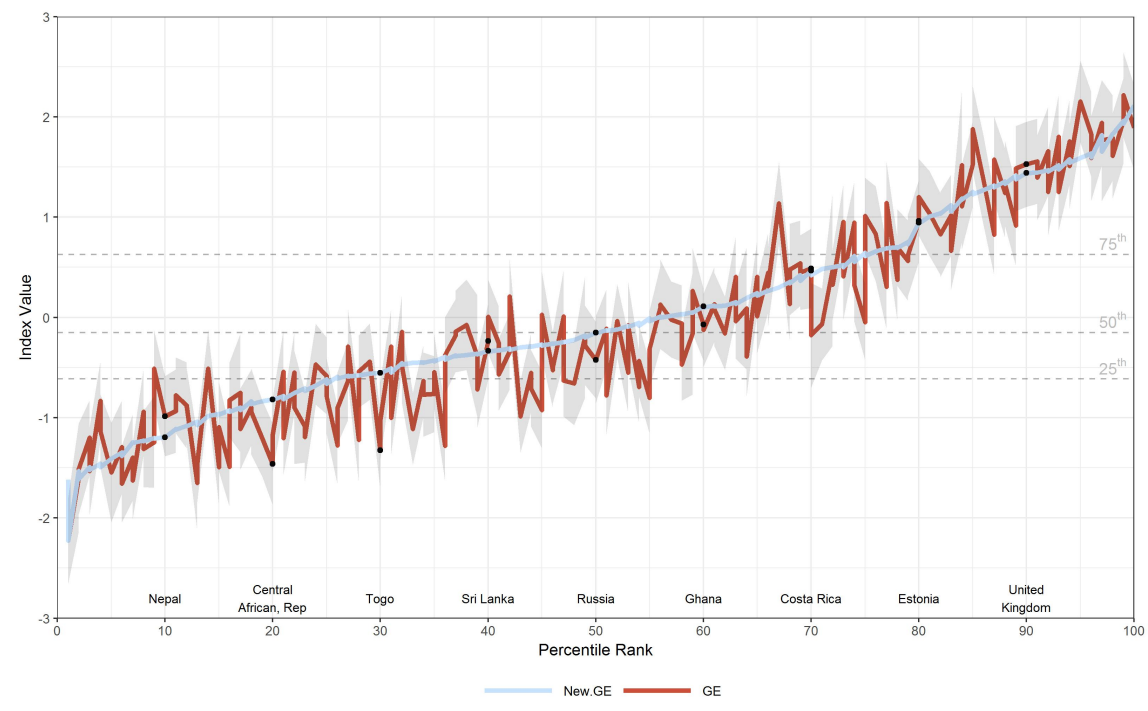

(a) Government Effectiveness

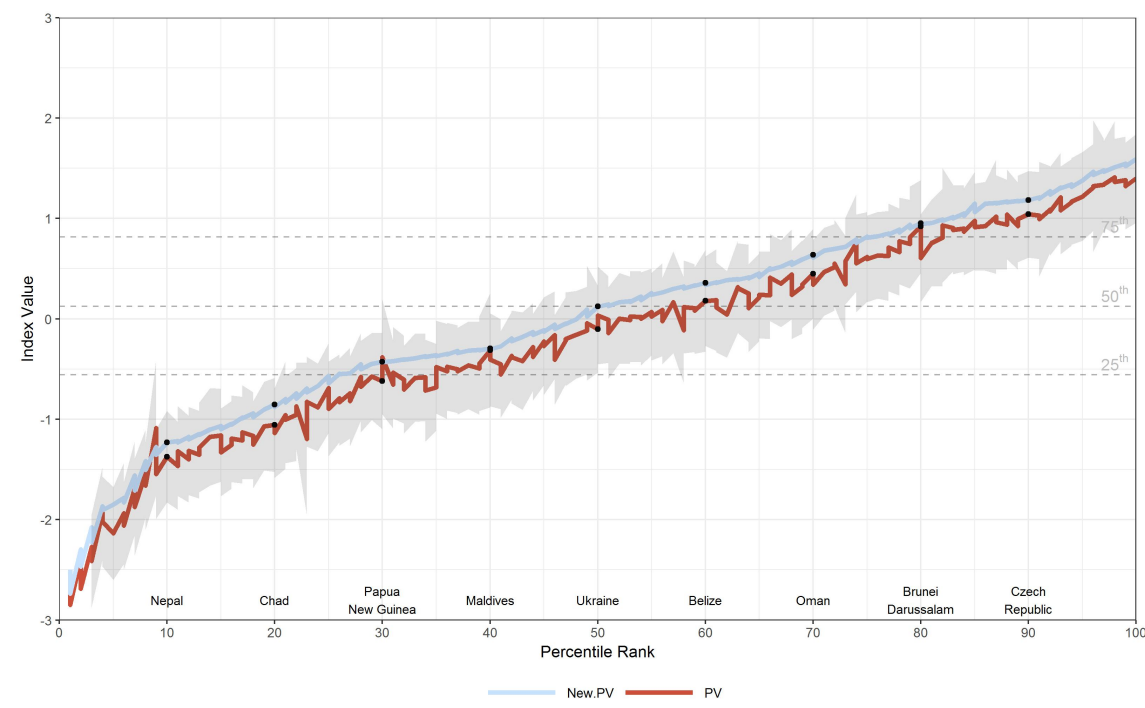

(b) Political Stability \& Absence of Violence



(c) Voice and Accountability

Figure 2: Reproduction of WGI I 


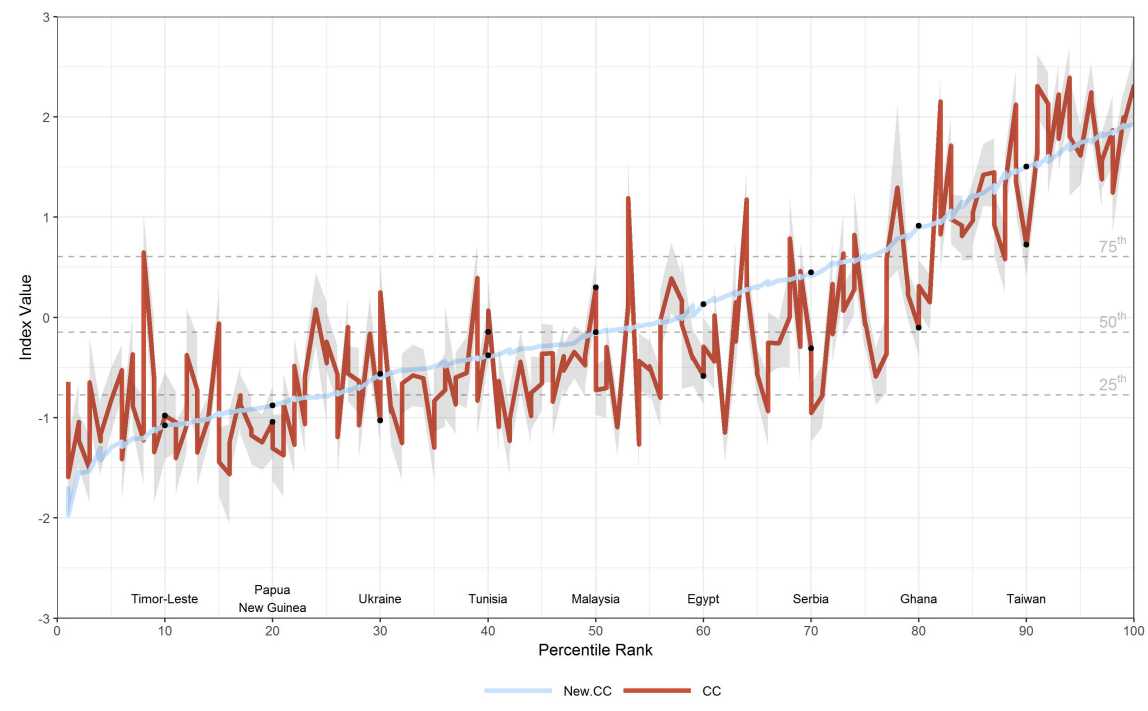

(a) Control of Corruption (continued)

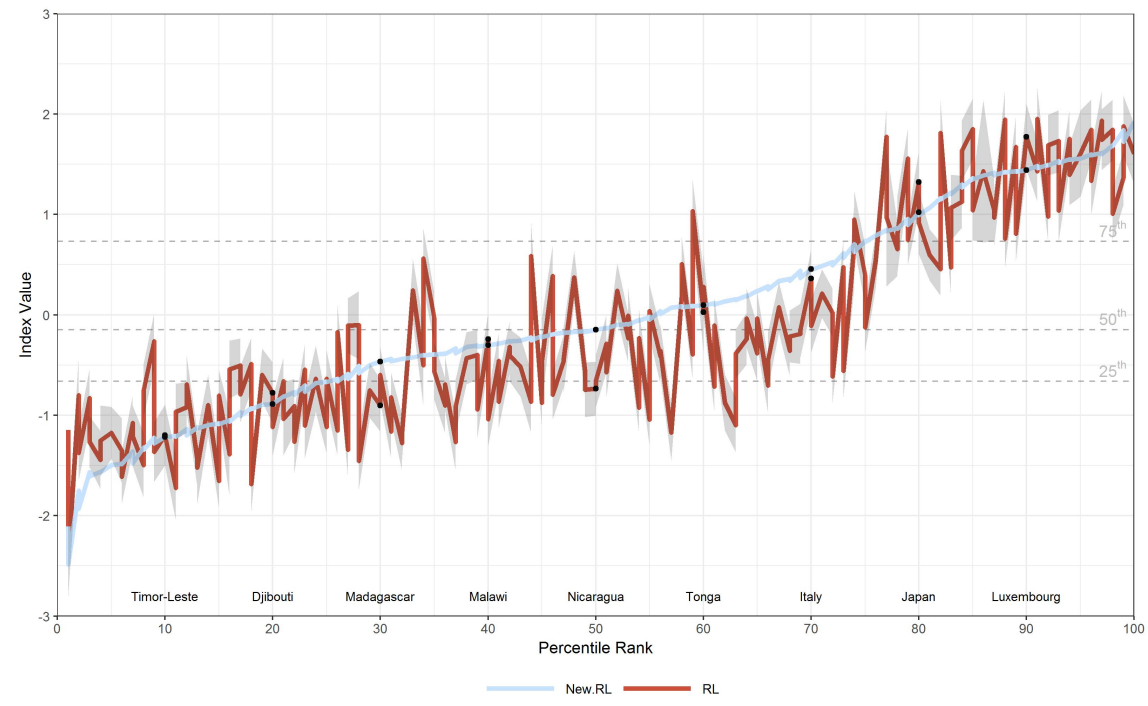

(b) Rule of Law

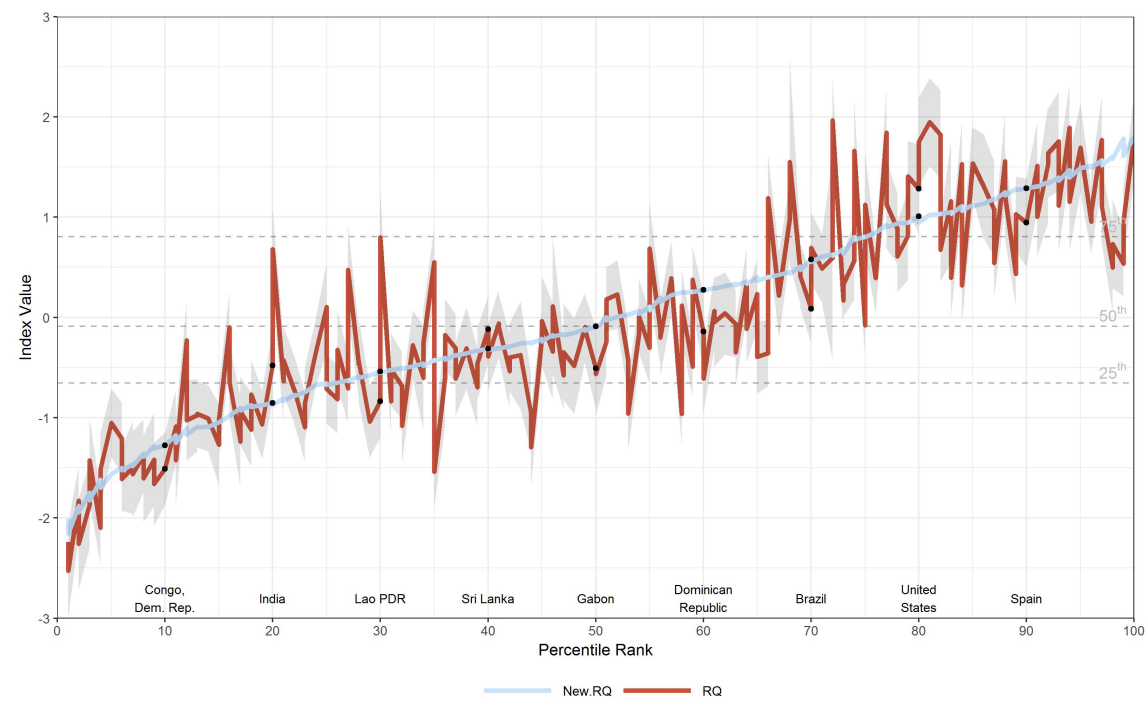

(c) Regulatory Quality

Figure 3: Reproduction of WGI II 


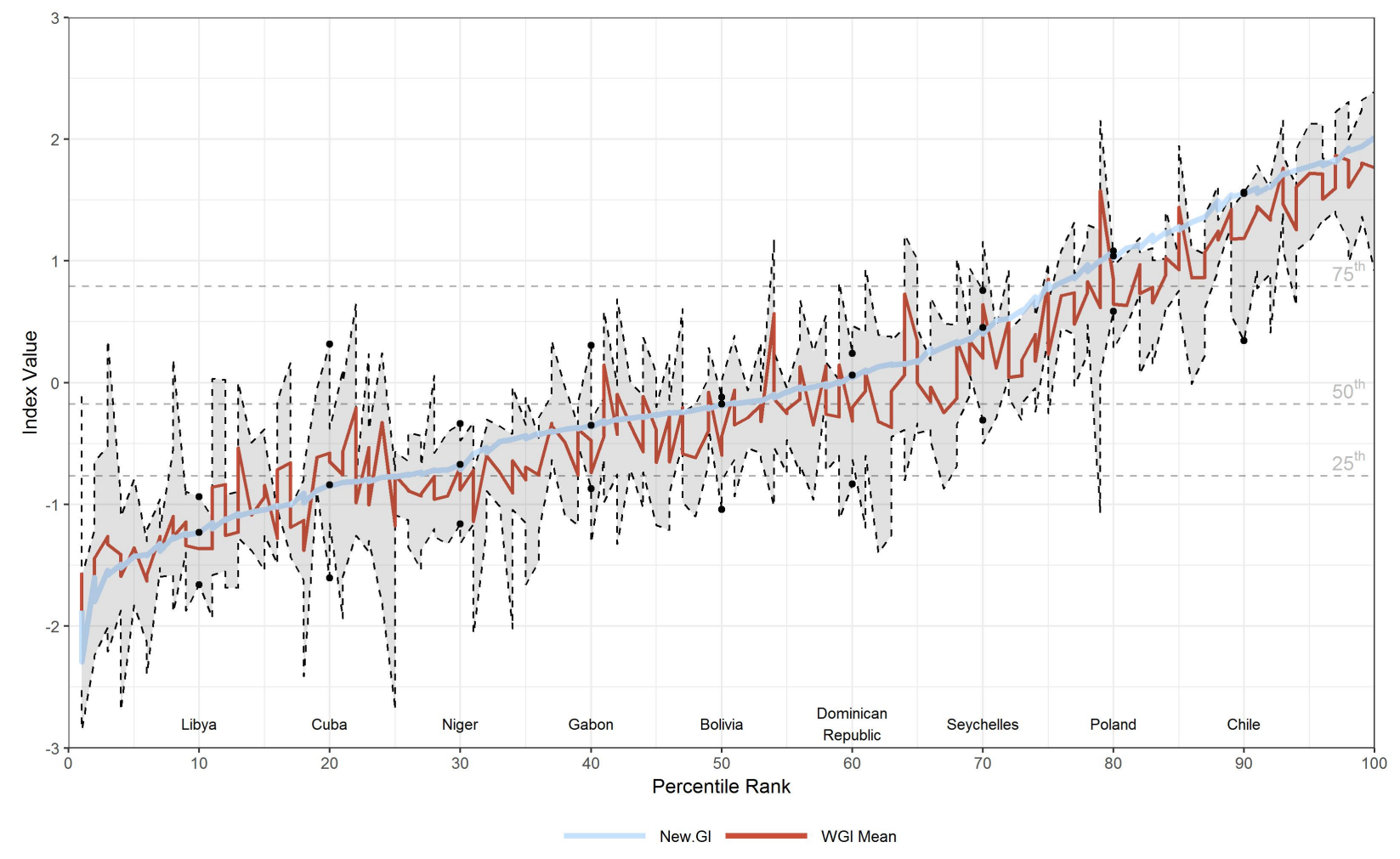

Figure 4: The New GI against the maximum and minimums of the WGI 


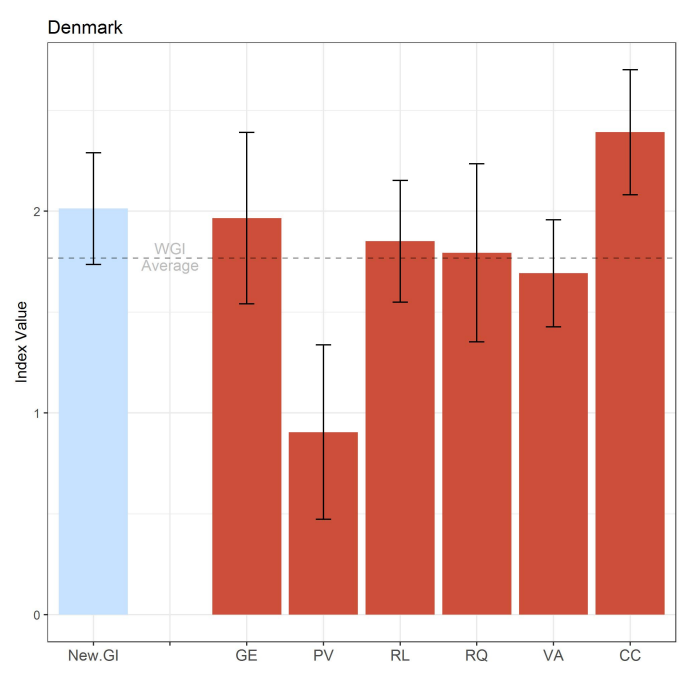

(a) Top Country: Denmark

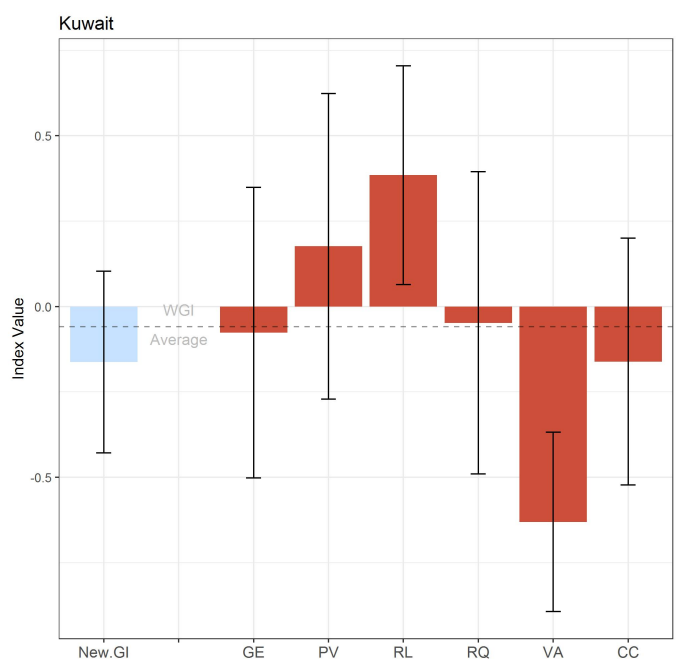

(c) Middle Country: Kuwait

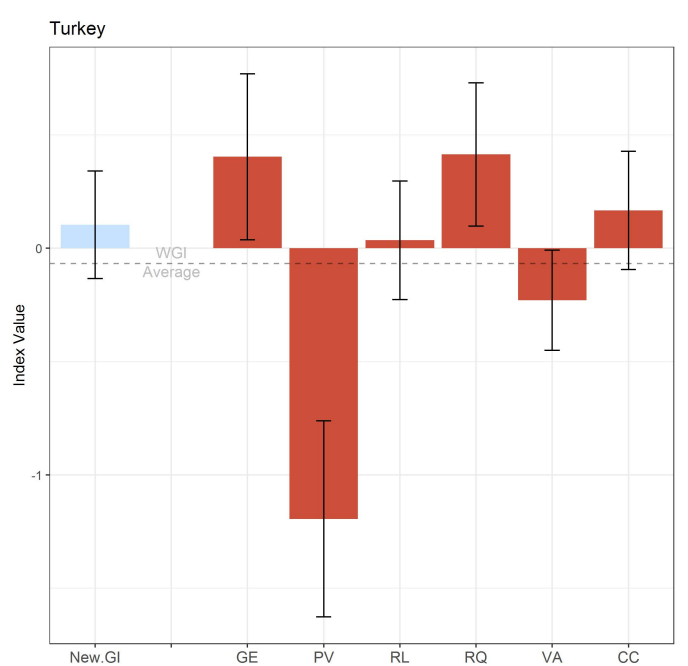

(e) Middle Country: Turkey

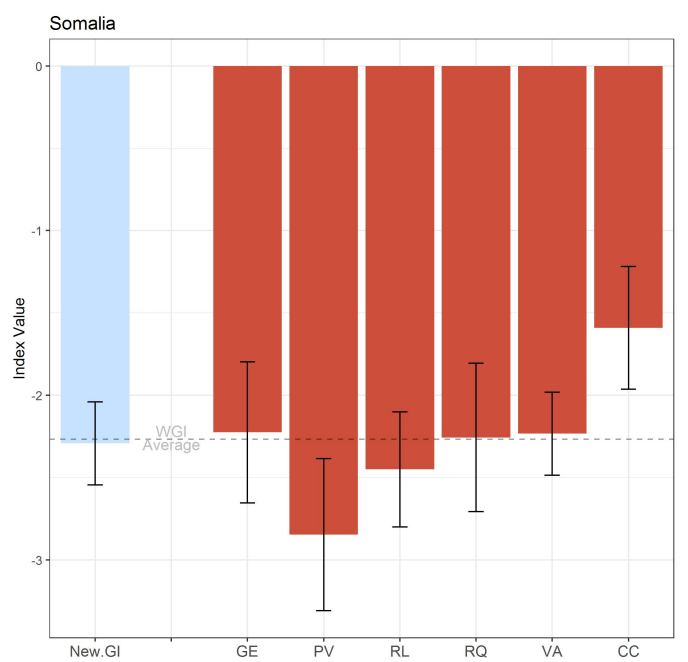

(b) Bottom Country: Somalia



(d) Middle Country: Bolivia

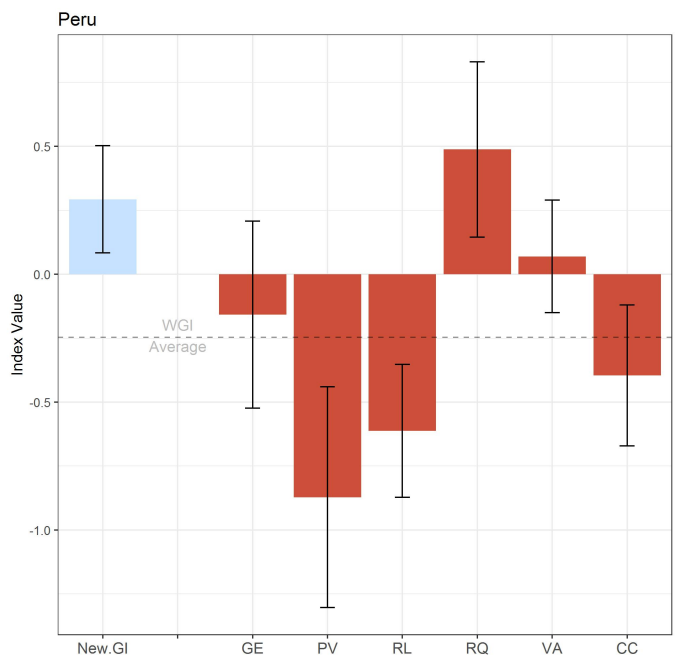

(f) Middle Country: Peru

Figure 5: The WGI and the New Governance Index 


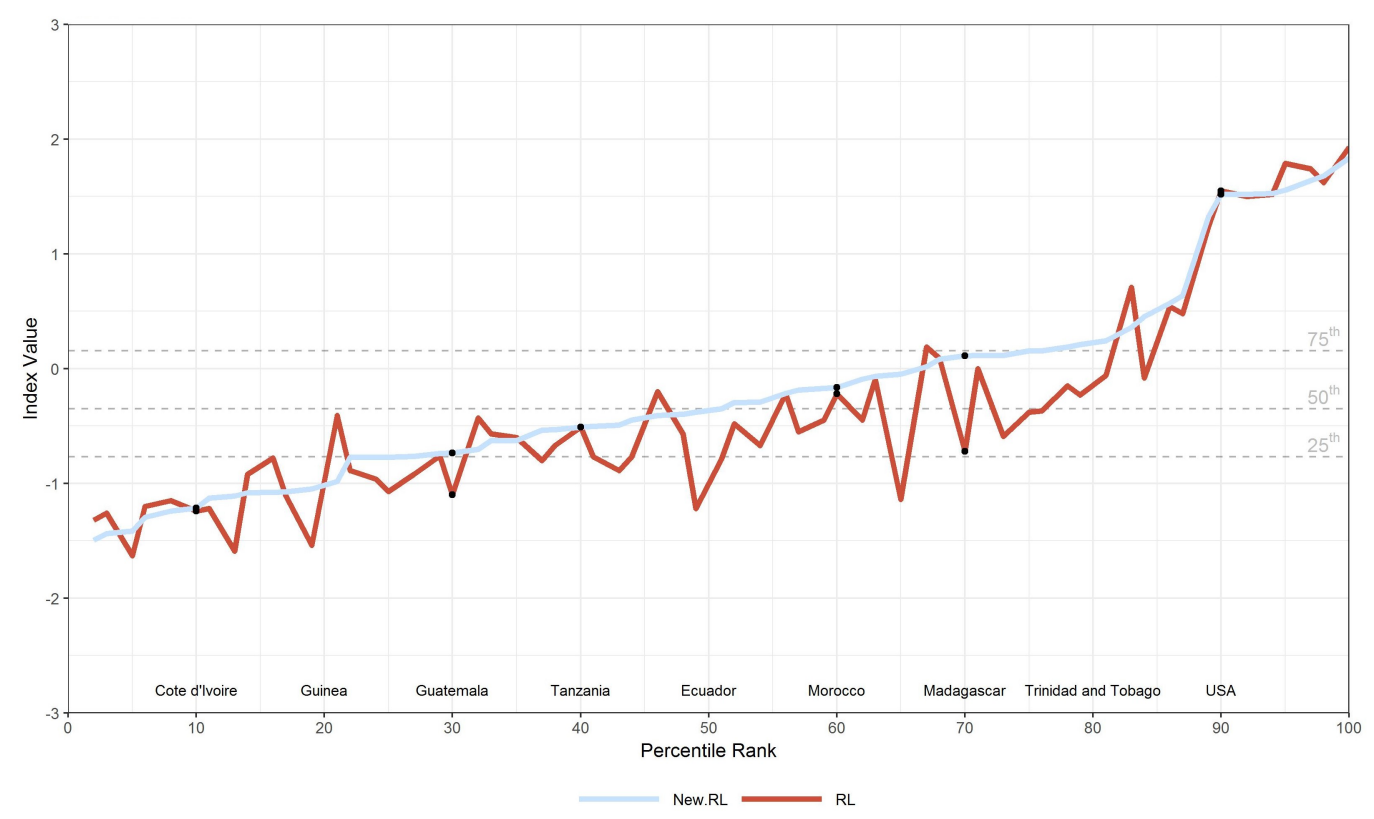

Figure 6: The original and re-estimated 2005 Rule of Law index 


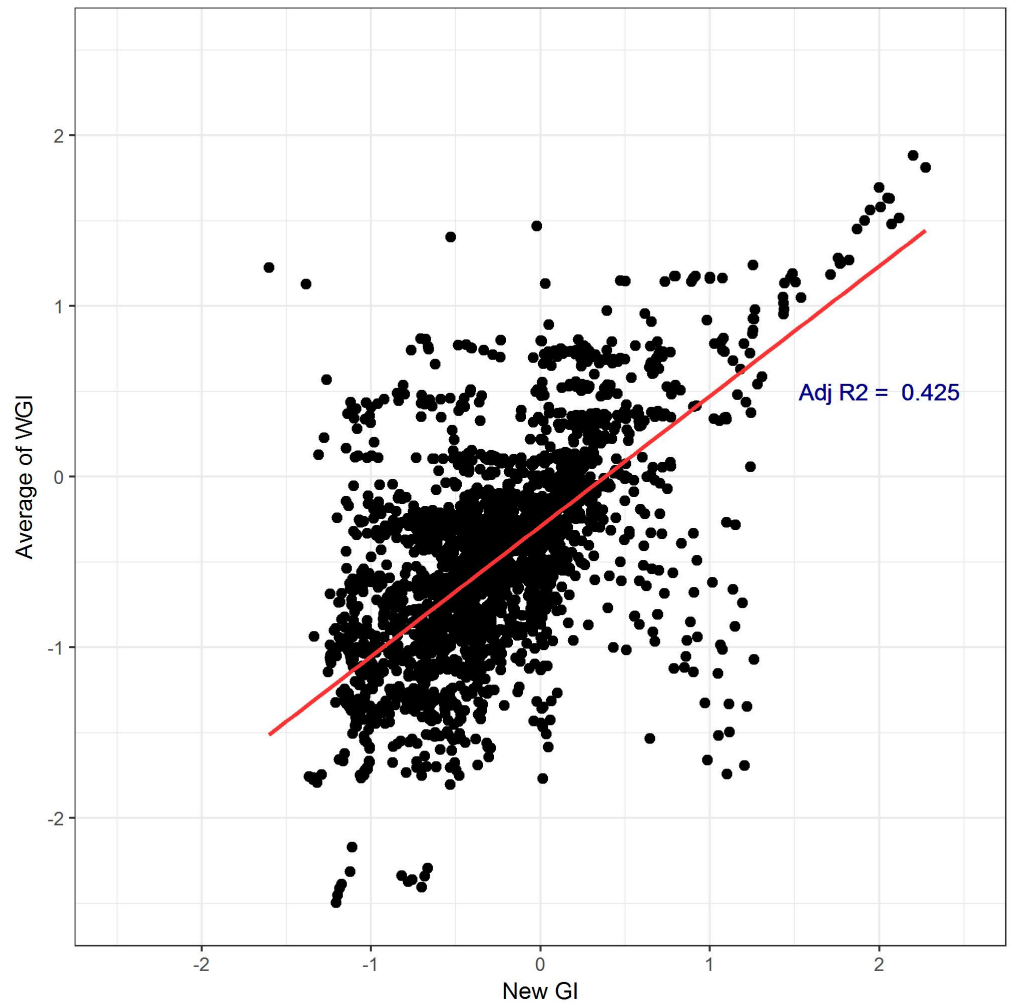

Figure 7: The constructed governance indicator against average of WGI 


\section{List of Tables}

$1 \quad$ Results of the first simulation study $\ldots \ldots \ldots \ldots \ldots$. . . . . . . . . 27

$2 \quad$ Number of baseline indicators for each WGI, 2012-13 . . . . . . . . . . . . . . 28

3 Tests of the statistical significance of group effect $\ldots \ldots \ldots \ldots$. . . . . . . . 29

4 Re-estimation of the results of Dollar and Kraay (2003): short run specitications 30

$5 \quad$ Re-estimation of the results of Acemoglu et al. $(2014)] \ldots \ldots$. . . . . . . 31

$6 \quad$ Re-estimation of the results of Winters and Martinez (2015) . . . . . . . . . . . . 32 
Table 1: Results of the first simulation study

\begin{tabular}{lccccc}
\hline & \multicolumn{2}{c}{ Balanced } & & \multicolumn{2}{c}{ Unbalanced } \\
& WGI & Proposed & & WGI & Proposed \\
\hline Mean Squared Error & 0.283 & 0.090 & & 4.858 & 0.043 \\
\hline $\operatorname{Prob}(\mid$ Rank Difference $\mid \leq 1)$ & $51.83 \%$ & $64.53 \%$ & & $60.35 \%$ & $70.26 \%$ \\
$\operatorname{Prob}(\mid$ Rank Difference $\mid \leq 5)$ & $68.39 \%$ & $78.64 \%$ & & $82.26 \%$ & $89.62 \%$ \\
\hline \hline
\end{tabular}

The number of Monte Carlo simulations is 1,000 with $M=15$ and $N=200$. 
Table 2: Number of baseline indicators for each WGI, 2012-13

\begin{tabular}{lc}
\hline WGI & Number of baseline indicators \\
\hline Control of Corruption (CC) & 21 \\
Government Effectiveness (GE) & 15 \\
Political Stability \& Absence of Violence (PV) & 9 \\
Rule of Law (RL) & 22 \\
Regulatory Quality (RQ) & 15 \\
Voice and Accountability (VA) & 19 \\
\hline Total & 101 \\
\hline \hline
\end{tabular}

Baseline indicators used, cover 179 countries in period of 2012-13. 
Table 3: Tests of the statistical significance of group effect

\begin{tabular}{lcc}
\hline Aspect & LR & t-stat \\
\hline Government Effectiveness (GE) & $176.37^{* * *}$ & $15.64^{* * *}$ \\
Political Stability \& Absence of Violence (PV) & $4.87^{*}$ & $4.25^{* * *}$ \\
Voice and Accountability (VA) & $191.93^{* * *}$ & $17.88^{* * *}$ \\
Control of Corruption (CC) & $906.83^{* * *}$ & $14.86^{* * *}$ \\
Rule of Law (RL) & $221.31^{* * *}$ & $19.33^{* * *}$ \\
Regulatory Quality (RQ) & $833.37^{* * *}$ & $15.98^{* * *}$ \\
\hline \hline $\begin{array}{l}\text { The } \mathcal{H}_{o}: \sigma_{v_{g}}^{2}=0, \\
{ }^{* * *} \mathrm{p}<0.01,{ }^{* *} \mathrm{p}<0.05,{ }^{*} \mathrm{p}<0.1\end{array}$ & \\
\hline
\end{tabular}


Table 4: Re-estimation of the results of Dollar and Kraay (2003): short run specitications

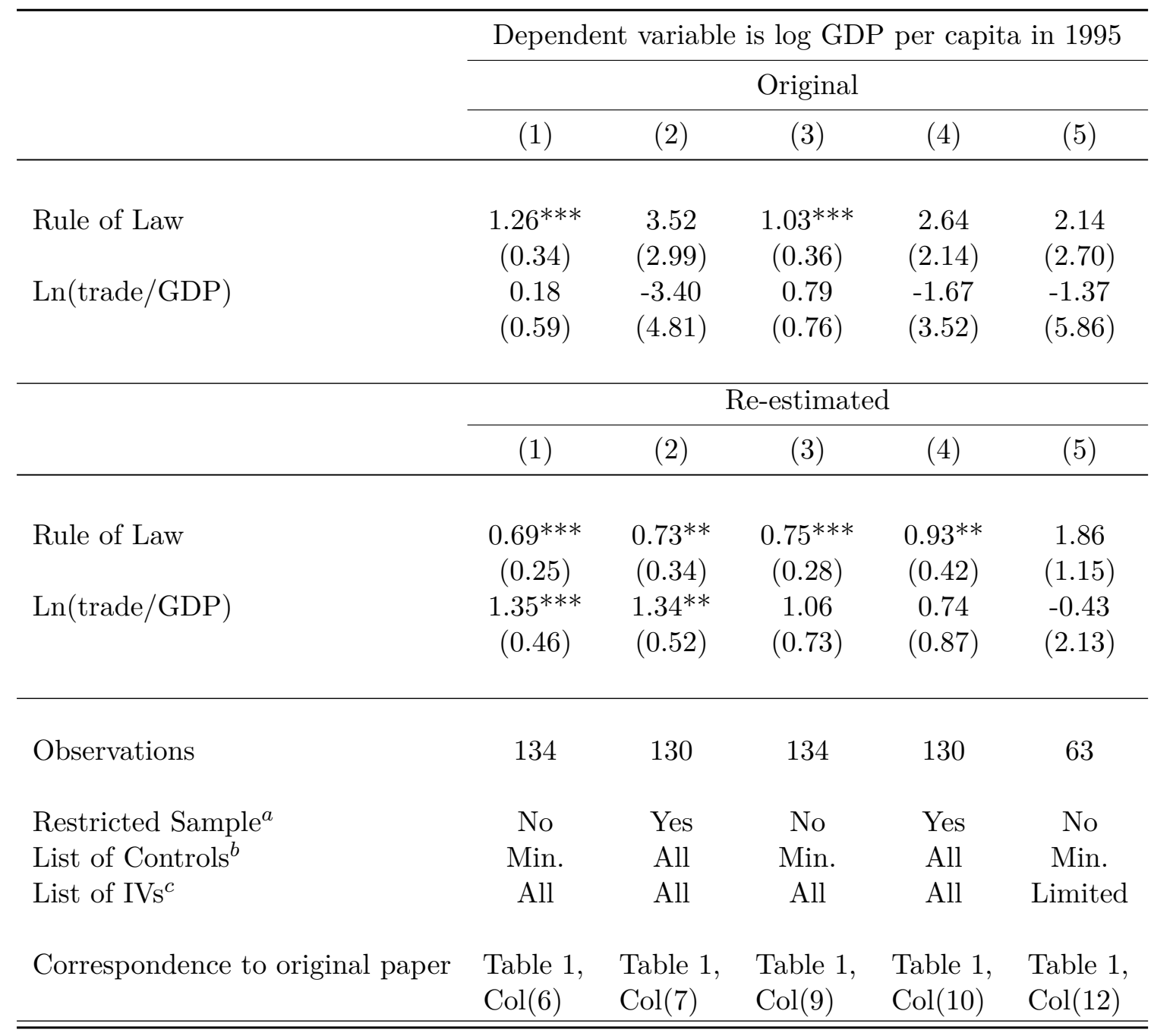

Robust standard errors clustered on country in parentheses. ${ }^{* * *} \mathrm{p}<0.01,{ }^{* *} \mathrm{p}<0.05,{ }^{*} \mathrm{p}<0.1$.

${ }^{a}$ In the restricted sample specifications, USA, CAN, AUS and NZL are dropped.

${ }^{b}$ The minimum of control variables (Min.) includes $\operatorname{Ln}$ (population). The All list comprises of the minimum list, landlock, distance from equator.

${ }^{c}$ The IV variables are share of population who speaks English, share of population who speaks a major European language, predicted trade and settler mortality. Column (5) uses limited IV, i.e. predicted trade and settler mortality. 
Table 5: Re-estimation of the results of Acemoglu et al. (2014)

\begin{tabular}{|c|c|c|c|c|}
\hline & \multicolumn{4}{|c|}{ Dependent variable is log GDP per capita in 2005} \\
\hline & \multicolumn{4}{|c|}{ Original } \\
\hline & (1) & $(2)$ & $(3)$ & $(4)$ \\
\hline Rule of Law & $\begin{array}{c}1.44^{* * *} \\
(0.43)\end{array}$ & $\begin{array}{l}1.79^{* *} \\
(0.72)\end{array}$ & $\begin{array}{l}1.19^{* *} \\
(0.47)\end{array}$ & $\begin{array}{c}2.24 \\
(1.89)\end{array}$ \\
\hline Years of schooling & & & $\begin{array}{c}0.14 \\
(0.15)\end{array}$ & $\begin{array}{l}-0.06 \\
(0.41)\end{array}$ \\
\hline \multirow{4}{*}{$\begin{array}{l}\mathrm{KP}^{a}, p \text {-value } \\
\mathrm{R} \text {-squared }^{b}\end{array}$} & 0.09 & 0.09 & 0.10 & 0.10 \\
\hline & 0.57 & 0.45 & 0.66 & 0.20 \\
\hline & \multicolumn{4}{|c|}{ Re-estimated } \\
\hline & $(1)$ & $(2)$ & $(3)$ & $(4)$ \\
\hline Rule of Law & $\begin{array}{c}1.28^{* * *} \\
(0.32)\end{array}$ & $\begin{array}{c}1.32^{* * *} \\
(0.36)\end{array}$ & $\begin{array}{c}1.09^{* * *} \\
(0.38)\end{array}$ & $\begin{array}{c}1.54 \\
(0.98)\end{array}$ \\
\hline Years of schooling & & & $\begin{array}{c}0.11 \\
(0.130)\end{array}$ & $\begin{array}{l}-0.01 \\
(0.30)\end{array}$ \\
\hline $\mathrm{KP}^{a}, p$-value & 0.02 & 0.02 & 0.03 & 0.03 \\
\hline $\mathrm{R}$-squared ${ }^{b}$ & 0.76 & 0.76 & 0.78 & 0.71 \\
\hline Observations & 62 & 62 & 62 & 62 \\
\hline Control variables & All & All & All & All \\
\hline Method of estimation & 2SLS & LIML & 2SLS & LIML \\
\hline Variable instrumented & Rule of Law & Rule of Law & Yrs Schooling & Rule of Law \\
\hline Instrumental variables & $\mathrm{IV}_{1}$ & $\mathrm{IV}_{1}$ & $\mathrm{IV}_{2}$ & $\mathrm{IV}_{2}$ \\
\hline Correspondence to original paper & $\begin{array}{l}\text { Col }(8), \\
\text { Table } 5\end{array}$ & $\begin{array}{l}\text { Col }(12), \\
\text { Table } 5\end{array}$ & $\begin{array}{l}\text { Col }(4), \\
\text { Table } 6\end{array}$ & $\begin{array}{l}\text { Col }(8), \\
\text { Table } 6\end{array}$ \\
\hline
\end{tabular}

${ }^{a} \mathrm{KP}$ : Kleibergen and Paap (2006)'s test.

${ }^{b}$ R-squared refers to first stage regression results.

All the control variables listed in the original papers are included. Table 5 control variable is Protestant missionaries in early $20^{t h}$ century and in Table 6 Rule of Law and Years of Schooling used as Right Hand Side (RHS) variables, where each treated as endogenous variable interchangeably.

Variables included in $\mathrm{IV}_{1}$ are log of capped potential settler mortality, log population density in 1500, primary school enrolment in 1900 , protestant missionaries in the early $20^{t h}$ century. $\mathrm{IV}_{2}$ is $\mathrm{IV}_{1}$ plus the primary school enrolment in 1870 .

Robust standard errors clustered on country in parentheses.

$* * * \mathrm{p}<0.01, * * \mathrm{p}<0.05, * \mathrm{p}<0.1$ 
Table 6: Re-estimation of the results of Winters and Martinez 2015)

\begin{tabular}{|c|c|c|c|c|c|c|}
\hline & \multicolumn{6}{|c|}{ Dependent variable log of Total Aid, 2004-10 } \\
\hline & \multicolumn{2}{|c|}{ Overall } & \multicolumn{2}{|c|}{ Modalities } & \multicolumn{2}{|c|}{ Sectors } \\
\hline & Bilateral & Multilateral & Bilateral & Multilateral & Bilateral & Multilateral \\
\hline & \multicolumn{6}{|c|}{ Original } \\
\hline & $(1)$ & $(2)$ & $(3)$ & $(4)$ & $(5)$ & (6) \\
\hline Governance & $\begin{array}{c}0.44^{* * *} \\
(0.12)\end{array}$ & $\begin{array}{l}0.26^{* *} \\
(0.11)\end{array}$ & $\begin{array}{c}0.12^{* * *} \\
(0.04)\end{array}$ & $\begin{array}{c}0.12 \\
(0.07)\end{array}$ & $\begin{array}{c}0.14^{* * *} \\
(0.05)\end{array}$ & $\begin{array}{c}0.12 \\
(0.07)\end{array}$ \\
\hline $\begin{array}{l}\text { Observations } \\
\text { R-squared }\end{array}$ & $\begin{array}{c}2,853 \\
0.27\end{array}$ & $\begin{array}{c}1,875 \\
0.30\end{array}$ & $\begin{array}{c}2,724 \\
0.17\end{array}$ & $\begin{array}{c}922 \\
0.06\end{array}$ & $\begin{array}{c}2,322 \\
0.15\end{array}$ & $\begin{array}{c}900 \\
0.10\end{array}$ \\
\hline \multirow{2}{*}{ R-squared } & \multicolumn{6}{|c|}{ Original, restricted sample ${ }^{a}$} \\
\hline & $(1)$ & $(2)$ & (3) & $(4)$ & (5) & $(6)$ \\
\hline Governance & $\begin{array}{c}0.54^{* * *} \\
(0.12)\end{array}$ & $\begin{array}{l}0.29^{* *} \\
(0.11)\end{array}$ & $\begin{array}{c}0.15^{* * *} \\
(0.04)\end{array}$ & $\begin{array}{l}0.11^{*} \\
(0.07)\end{array}$ & $\begin{array}{c}0.17^{* * *} \\
(0.05)\end{array}$ & $\begin{array}{c}0.12 \\
(0.07)\end{array}$ \\
\hline Observations & 2,631 & 1,732 & 2,511 & 853 & 2,168 & 837 \\
\hline \multirow[t]{3}{*}{ R-squared } & 0.23 & 0.25 & 0.14 & 0.05 & 0.14 & 0.09 \\
\hline & \multicolumn{6}{|c|}{ Re-estimated } \\
\hline & $(1)$ & $(2)$ & $(3)$ & $(4)$ & $(5)$ & $(6)$ \\
\hline Governance & $\begin{array}{c}0.24 \\
(0.19)\end{array}$ & $\begin{array}{c}0.18 \\
(0.16)\end{array}$ & $\begin{array}{c}0.07 \\
(0.05)\end{array}$ & $\begin{array}{c}0.02 \\
(0.06)\end{array}$ & $\begin{array}{l}0.12^{*} \\
(0.07)\end{array}$ & $\begin{array}{l}-0.02 \\
(0.07)\end{array}$ \\
\hline Observations & 2,631 & 1,732 & 2,511 & 853 & 2,168 & 837 \\
\hline R-squared & 0.22 & 0.25 & 0.14 & 0.04 & 0.14 & 0.09 \\
\hline Donors $^{b}$ & 41 & 39 & 36 & 18 & 34 & 18 \\
\hline $\begin{array}{l}\text { Correspondence } \\
\text { to original paper }\end{array}$ & $\begin{array}{l}\text { Col }(1), \\
\text { Table } 3\end{array}$ & $\begin{array}{l}\text { Col }(2), \\
\text { Table } 3\end{array}$ & $\begin{array}{l}\text { Col }(1) \\
\text { Table } 4\end{array}$ & $\begin{array}{l}\text { Col }(2) \\
\text { Table } 4\end{array}$ & $\begin{array}{l}\text { Col }(3) \\
\text { Table } 4\end{array}$ & $\begin{array}{l}\text { Col }(4) \\
\text { Table } 4\end{array}$ \\
\hline
\end{tabular}

In all columns, controls include $\ln \left(\right.$ GDP per capita), $\ln (\text { GDP per capita })^{2}$, External debt ratio, investment ratio, $\ln$ (population), $\ln$ (trade), if was former colony, if was part of alliance. In those specifications where the sample is restricted to multilateral donors $\ln$ (trade) and if was part of alliance were excluded from regression. Refer to the original paper for further details.

${ }^{a}$ As using the re-constructed indicator changes the number of observation in the sample. Original sample was restricted to the one used in re-estimation to check if the differences in the results are due the changes in the sample.

${ }^{b}$ number of donors did not changes by using the re-estimated governance measure.

Robust standard errors clustered on donor in parentheses.

*** $\mathrm{p}<0.01,{ }^{* *} \mathrm{p}<0.05,{ }^{*} \mathrm{p}<0.1$ 
Editor, UWA Economics Discussion Papers:

Sam Hak Kan Tang

University of Western Australia

35 Sterling Hwy

Crawley WA 6009

Australia

Email: ecoadmin@biz.uwa.edu.au

The Economics Discussion Papers are available at:

Since 1980: $\quad$ https://ideas.repec.org/s/uwa/wpaper.html

Since 2004: http://www.business.uwa.edu.au/school/disciplines/economics

\begin{tabular}{|c|c|c|}
\hline \multicolumn{3}{|c|}{ ECONOMICS DISCUSSION PAPERS - 2016} \\
\hline $\begin{array}{l}\text { DP } \\
\text { NUMBER }\end{array}$ & AUTHORS & TITLE \\
\hline 16.01 & Xu, R., Wu, Y. and Luan, J. & $\begin{array}{l}\text { ANALYSIS OF FARMERS’ WILLINGNESS TO ADOPT } \\
\text { GENETICALLY MODIFIED INSECT-RESISTANT RICE IN } \\
\text { CHINA }\end{array}$ \\
\hline 16.02 & $\begin{array}{l}\text { Lia, Y., Fan, J., Zhao, D., Wu, Y. and } \\
\text { Li, J. }\end{array}$ & $\begin{array}{l}\text { TIERED GASOLINE PRICING: A PERSONAL CARBON } \\
\text { TRADING PERSPECTIVE }\end{array}$ \\
\hline 16.03 & Clements, K.W., Lan, Y. and Si, J. & UNCERTAINTY IN CURRENCY MISPRICING \\
\hline 16.04 & Parsons, C. and Vézina, P.L. & $\begin{array}{l}\text { MIGRANT NETWORKS AND TRADE:THE VIETNAMESE } \\
\text { BOAT PEOPLE AS A NATURAL EXPERIMENT }\end{array}$ \\
\hline 16.05 & Chang, S., Connelly, R. and Ma, P. & $\begin{array}{l}\text { WHAT WILL YOU DO IF I SAY 'I DO’?: THE EFFECT OF } \\
\text { THE SEX RATIO ON TIME USE WITHIN TAIWANESE } \\
\text { MARRIED COUPLES }\end{array}$ \\
\hline 16.06 & Yu, F. and Wu, Y. & $\begin{array}{l}\text { BIASES IN PATENT EXAMINATION AND FIRMS’ } \\
\text { RESPONSES: EVIDENCE FROM THE } \\
\text { PHARMACEUTICAL INDUSTRY }\end{array}$ \\
\hline 16.07 & $\begin{array}{l}\text { Fan, J., Li, J., Wu, Y., Wang, S. and } \\
\text { Zhao, D. }\end{array}$ & $\begin{array}{l}\text { THE EFFECTS OF ALLOWANCE PRICE ON ENERGY } \\
\text { DEMAND UNDER A PERSONAL CARBON TRADING } \\
\text { SCHEME }\end{array}$ \\
\hline 16.08 & Golley, J., Tyers, R. and Zhou, Y. & $\begin{array}{l}\text { CONTRACTIONS IN CHINESE FERTILITY AND } \\
\text { SAVINGS: LONG RUN DOMESTIC AND GLOBAL } \\
\text { IMPLICATIONS }\end{array}$ \\
\hline 16.09 & McGrath, G. and Neill, K. & $\begin{array}{l}\text { FOREIGN AND DOMESTIC OWNERSHIP IN WESTERN } \\
\text { AUSTRALIA'S GAS MARKET }\end{array}$ \\
\hline 16.10 & Clements, K.W. and Si, J. & SIMPLIFYING THE BIG MAC INDEX \\
\hline 16.11 & Priyati, R.Y. and Tyers, R. & $\begin{array}{l}\text { PRICE RELATIONSHIPS IN VEGETABLE OIL AND } \\
\text { ENERGY MARKETS }\end{array}$ \\
\hline 16.12 & Wu, J., Wu, Y. and Wang, B. & $\begin{array}{l}\text { THE GREENNESS OF CHINESE CITIES: CARBON } \\
\text { DIOXIDE EMISSION AND ITS DETERMINANTS }\end{array}$ \\
\hline 16.13 & $\begin{array}{l}\text { Arslan, C., Dumont, J.C., Kone, Z., } \\
\text { Özden, Ç., Parsons, C. and } \\
\text { Xenogiani, T. }\end{array}$ & $\begin{array}{l}\text { INTERNATIONAL MIGRATION TO THE OECD IN THE } \\
\text { TWENTY-FIRST CENTURY }\end{array}$ \\
\hline 16.14 & Tomioka, K. and Tyers, R. & $\begin{array}{l}\text { HAS FOREIGN GROWTH CONTRIBUTED TO } \\
\text { STAGNATION AND INEQUALITY IN JAPAN? }\end{array}$ \\
\hline 16.15 & Donovan, J. and Hartley, P. & RIDING THE IRON ORE CYCLE: ACTIONS OF \\
\hline
\end{tabular}




\begin{tabular}{|l|l|l|}
\hline 16.16 & Czaika, M. and Parsons, C. & $\begin{array}{l}\text { AUSTRALIA'S MAJOR PRODUCERS } \\
\text { HIGH-SKILLED MIGRATION IN TIMES OF GLOBAL } \\
\text { ECONOMIC CRISIS }\end{array}$ \\
\hline 16.17 & Lefroy, T., Key, J. and Kingwell, R. & $\begin{array}{l}\text { A LONGITUDINAL EXAMINATION OF BROADACRE } \\
\text { FARM SIZE AND PERFORMANCE IN WESTERN } \\
\text { AUSTRALIA }\end{array}$ \\
\hline 16.18 & Arthmar, R. and McLure, M. & $\begin{array}{l}\text { SRAFFA, MYRDAL AND THE 1961 SÖDERSTRÖM GOLD } \\
\text { MEDAL }\end{array}$ \\
\hline 16.19 & Azwar, P. and Tyers, R. & $\begin{array}{l}\text { POST-GFC EXTERNAL SHOCKS AND INDONESIAN } \\
\text { ECONOMIC PERFORMANCE }\end{array}$ \\
\hline 16.20 & Chen, A. and Groenewold, N. & $\begin{array}{l}\text { OUTPUT SHOCKS IN CHINA: DO THE DISTRIBUTIONAL } \\
\text { EFFECTS DEPEND ON THE REGIONAL SOURCE? }\end{array}$ \\
\hline 16.21 & Wu, Y., Zhu, X. and Groenewold, N. & $\begin{array}{l}\text { THE DETERMINANTS AND EFFECTIVENESS OF } \\
\text { INDUSTRIAL POLICY IN CHINA: A STUDY BASED ON } \\
\text { FIVE-YEAR PLANS }\end{array}$ \\
\hline 16.22 & Liu, H. & $\begin{array}{l}\text { THE INCOME AND PRICE SENSITIVITY OF DIETS } \\
\text { GLOBALLY }\end{array}$ \\
\hline 16.23 & Asano, A., Neill, K. and Yamazaki, S. & $\begin{array}{l}\text { DECOMPOSING FISHING EFFORT: MODELLING THE } \\
\text { SOURCES OF INEFFICIENCY IN A LIMITED-ENTRY } \\
\text { FISHERY }\end{array}$ \\
\hline 16.24 & Golley, J., Tyers, R. and Zhou, Y. & $\begin{array}{l}\text { FERTILITY AND SAVINGS CONTRACTIONS IN CHINA: } \\
\text { LONG-RUN GLOBAL IMPLICATIONS }\end{array}$ \\
\hline 16.25 & Taylor, G., Tyers, R. & $\begin{array}{l}\text { SECULAR STAGNATION: DETERMINANTS AND } \\
\text { CONSEQUENCES FOR AUSTRALIA }\end{array}$ \\
\hline
\end{tabular}

\begin{tabular}{|c|c|c|}
\hline \multicolumn{3}{|c|}{ ECONOMICS DISCUSSION PAPERS - 2017} \\
\hline $\begin{array}{c}\text { DP } \\
\text { NUMBER }\end{array}$ & AUTHORS & TITLE \\
\hline 17.01 & Tyers, R. and Zhou, Y. & $\begin{array}{l}\text { AUTOMATION AND INEQUALITY WITH TAXES AND } \\
\text { TRANSFERS }\end{array}$ \\
\hline 17.02 & Ye, L. and Robertson, P. & $\begin{array}{l}\text { HITTING THE GREAT WALL: RURAL-URBAN } \\
\text { MIGRATION AND CHINA'S GROWTH SLOWDOWN }\end{array}$ \\
\hline 17.03 & Ye, L. and Robertson, P. & $\begin{array}{l}\text { MIGRATION AND GROWTH IN CHINA: A SCEPTICAL } \\
\text { ASSESSMENT OF THE EVIDENCE }\end{array}$ \\
\hline 17.04 & Clements, K. Si, J. and Vo, L. & $\begin{array}{l}\text { FOOD AND AGRICULTURAL PRICES ACROSS } \\
\text { COUNTRIES AND THE LAW OF ONE PRICE }\end{array}$ \\
\hline 17.05 & $\begin{array}{l}\text { Chen, M., Clements, K., Gao, G. and } \\
\text { Si, J. }\end{array}$ & THREE FACTS ABOUT WORLD METAL PRICES \\
\hline 17.06 & $\begin{array}{l}\text { Cornes, R., Fiorini, L. and } \\
\text { Maldonado, W. }\end{array}$ & $\begin{array}{l}\text { EXPECTATIONAL STABILITY IN AGGREGATIVE } \\
\text { GAMES }\end{array}$ \\
\hline 17.07 & Hartley, P. & $\begin{array}{l}\text { THE COST OF DISPLACING FOSSIL FUELS: SOME } \\
\text { EVIDENCE FROM TEXAS }\end{array}$ \\
\hline 17.08 & Shehabi, M. R. & ASSESSING KUWAITI ENERGY PRICINING REFORMS \\
\hline 17.09 & Perdana, S. and Tyers, R. & $\begin{array}{l}\text { GLOBAL CLIMATE CHANGE MITIGATION: STRATEGIC } \\
\text { INTERACTION OR UNILATERAL GAINS? }\end{array}$ \\
\hline 17.10 & McLure, M. & $\begin{array}{l}\text { RICARDIAN EQUIVALENCE, THE ITALIAN FISCAL } \\
\text { TRADITION AND WA GOVERNMENT NET DEBT }\end{array}$ \\
\hline 17.11 & Trinh, J. & $\begin{array}{l}\text { THE PARETO DISTRIBUTION AND ITS RELATIONSHIP } \\
\text { TO PIKETTY'S THIRD FUNDAMENTAL LAW OF } \\
\text { CAPITALISM }\end{array}$ \\
\hline 17.12 & McLure, M. & THINKING OUTSIDE THE BOX: A NEW HISTORY OF \\
\hline
\end{tabular}




\begin{tabular}{|c|c|c|}
\hline & & $\begin{array}{l}\text { EDGEWORTH'S AND PARENTO'S DEVELOPMENT OF } \\
\text { THE BOX DIAGRAM }\end{array}$ \\
\hline 17.13 & Zhou, Y. and Tyers, R. & AUTOMATION AND INEQUALITY IN CHINA \\
\hline 17.14 & Arthmar, R. and McLure, M. & $\begin{array}{l}\text { THE ECONOMIC AND SOCIAL CONSEQUENCES OF THE } \\
\text { WAR: PIGOU, THE PRESS AND THE STRUGGLE FOR AN } \\
\text { HONOURABLE PEACE }\end{array}$ \\
\hline 17.15 & Shehabi, M. R. & $\begin{array}{l}\text { CONTEMPORARY KUWAITISATION DYNAMICS AND } \\
\text { THEIR HISTORICAL PERSPECTIVES }\end{array}$ \\
\hline 17.16 & Clements, K. and Si, J. & $\begin{array}{l}\text { WHAT DO AUSTRALIAN ECONOMICS PhDs DO? THE } \\
\text { UWA EXPERIENCE }\end{array}$ \\
\hline 17.17 & Arthmar, R. and McLure, M. & KEYNES AND THE ROYAL SWEDISH ACADEMY \\
\hline 17.18 & Chen, A. and Groenewold, N. & $\begin{array}{l}\text { CHINA’S ‘NEW NORMAL’: IS THE GROWTH } \\
\text { SLOWDOWN DEMAND- OR SUPPLY- DRIVEN? }\end{array}$ \\
\hline 17.19 & Groenewold, N. & $\begin{array}{l}\text { CHINA'S ‘NEW NORMAL’: HOW WILL CHINA’S } \\
\text { GROWTH SLOWDOWN AFFECT AUSTRALIA'S } \\
\text { GROWTH? }\end{array}$ \\
\hline
\end{tabular}

ECONOMICS DISCUSSION PAPERS - 2018

\begin{tabular}{|c|c|c|}
\hline $\begin{array}{c}\text { DP } \\
\text { NUMBER }\end{array}$ & AUTHORS & TITLE \\
\hline 18.01 & Tyers, R. and Zhou, Y. & LOST INFLATION? \\
\hline 18.02 & McLure, M. & PARETIAN FISCAL SOCIOLOGY \\
\hline 18.03 & McLure, M. and Montesano, A. & $\begin{array}{l}\text { THINKING OUTSIDE THE BOX: EDGEWORTH, PARETO } \\
\text { AND THE EARLY HISTORY OF THE BOX DIAGRAM }\end{array}$ \\
\hline 18.04 & Tyers, R. and Zhou, Y. & DEFLATION FORCES AND INEQUALITY \\
\hline 18.05 & Clements, K. and Si, J. & DIVISIA AND FRISCH ARE FRIENDS \\
\hline 18.06 & Trinh, J. and McLure, M. & $\begin{array}{l}\text { PILETTY'S }(\mathrm{r}-\mathrm{g}) \text { LAW IS PARETO'S LAW: CONSISTENT } \\
\text { ANALYSES OF INCOME DISTRIBUTION PREDICATED ON } \\
\text { INCONSISTENT DEFINITIONS OF INEQUALITY }\end{array}$ \\
\hline 18.07 & Tyers, R. and Zhou, Y. & $\begin{array}{l}\text { AUTOMATION, TAXES AND TRANSFERS } \\
\text { WITH INTERNATIONAL RIVALRY }\end{array}$ \\
\hline 18.08 & Li, Q., Vo, L. H. and Wu, Y. & INTANGIBLE CAPITAL DISTRIBUTION IN CHINA \\
\hline 18.09 & Vo, L. H. & $\begin{array}{l}\text { WHY DON'T AGRICULTURAL PRICES ALWAYS ADJUST } \\
\text { TOWARDS PARITY? }\end{array}$ \\
\hline 18.10 & Magnusson, L. M. and Tarverdi, Y. & MEASURING GOVERNANCE: WHY DO ERRORS MATTER? \\
\hline
\end{tabular}

